University of the Pacific

Scholarly Commons

College of the Pacific Faculty Books and Book

Chapters

All Faculty Scholarship

$12-19-2016$

\title{
Mill's Philosophy of Religion
}

Lou Matz

University of the Pacific, Imatz@pacific.edu

Follow this and additional works at: https://scholarlycommons.pacific.edu/cop-facbooks

Part of the Philosophy Commons

\section{Recommended Citation}

Matz, L. (2016). Mill's Philosophy of Religion. In Christopher Macleod and Dale E. Miller (Eds.), A Companion to Mill (279-294). Hoboken, NJ: Wiley-Blackwell

https://scholarlycommons.pacific.edu/cop-facbooks/183

This Contribution to Book is brought to you for free and open access by the All Faculty Scholarship at Scholarly Commons. It has been accepted for inclusion in College of the Pacific Faculty Books and Book Chapters by an authorized administrator of Scholarly Commons. For more information, please contact mgibney@pacific.edu. 
A Companion to Mill

\author{
Edited by \\ Christopher Macleod and Dale E. Miller
}




\title{
19
}

\section{Mill's Philosophy of Religion}

\author{
LOU J. MATZ
}

Based on his published writings during his lifetime, Mill had the reputation as an outspoken apologist for religious liberty, an admirer and critic of Christian morality, a sceptic on miracles, and an advocate that utilitarianism could be established as a religion. When Mill's Autobiography appeared after his death, it reinforced the suspicion that he rejected supernatural religious hope and embraced a secularism in which a utilitarian morality and the virtues of character constituted the best religion. A Unitarian reviewer wondered whether Mill might regret depriving humans of "Divine trust and hope" despite acknowledging in his Autobiography the vital role of the feelings and emotions for human well-being. ${ }^{.}$However, the publication in the next year of Mill's Three Essays on Religion - Nature, Utility of Religion, and Theism - surprised everyone, for the celebrated author of the System of Logic judged, in his essay Theism, the design argument to be weakly probable and defended the legitimacy of hope in an afterlife and revelation. Mill's friend and biographer, Alexander Bain, apparently asked Mill's stepdaughter, Helen Taylor, to edit the essays to save Mill's reputation. Mill wrote Nature and Utility of Religion between 1850-58, whereas Theism was written between 1868-70, near the end of Mill's life. Nature is an analysis, and critique, of the theory of natural moral law. Utility of Religion is an exploration of the question whether supernatural religions, such as Christianity, are necessary for individual and social well-being. And Theism is Mill's examination of the scientific evidence for the main tenets of supernatural religion - the existence and attributes of God, immortality, and miracles - and the legitimacy of imaginative supernatural hope.

The publication of the Three Essays attracted an immediate and considerable reaction (Sell 1997), but Mill's philosophy of religion, stated in the Three Essays, remains regrettably unknown today, and there has been little scholarly attention devoted to it, which is surprising given that his critique of supernatural religion and appropriation of it is essential for a full understanding of his moral theory, theory of human well-being, and his approach to social reform. ${ }^{2}$ Mill's philosophy of religion

A Companion to Mill, First Edition. Edited by Christopher Macleod and Dale E. Miller.

(C) 2017 John Wiley \& Sons, Inc. Published 2017 by John Wiley \& Sons, Inc. 
LOU J. MATZ

also makes a nuanced contribution to the current debate about the value of religion spawned by the so-called new atheists. ${ }^{3}$

\section{Mill's Position and Historical Climate}

For Mill, religions provide ideals to guide and inspire human conduct about ultimate aims. He defines the essence of religion as:

the strong and earnest direction of the emotions and desires toward an ideal object, recognized as of the highest excellence, and as rightfully paramount over all selfish objects of desire. (Utility of Religion, X: 422)

His philosophy of religion can be summed up in one sentence: Improve yourself and society, and if you need the motivation to do so, it is legitimate to hope in supernatural realities that are consistent with reason and moral feelings. Contrary to the position of many commentators (Hamburger 1991; Raeder 2002; Sell 2004), Mill did not think that a secular Religion of Humanity, freed of any supernatural hope, was the highest form of religious belief, the most enlightened Weltanschauung. He thought such a secular religion was possible and that it had advantages over supernatural religions such as Christianity. While he claimed that the most important quality of any opinion on any momentous subject is its truth or falsity and that the "legitimate conclusions of science are entitled to prevail over all opinions, however widely held, which conflict with them" (Theism, X: 431), Mill held that the literal truth of facts is not the only thing to be considered when theorizing about human well-being. He believed that since people have different temperaments and feelings, cultivating hope in the existence of a benevolent deity and an afterlife could fortify a Religion of Humanity without detracting from the progress of the sciences and morality. Mill thus did not think that the fortification of a Religion of Humanity with supernatural hopes was merely a transitional stage in history, necessary for the successful reform of religion and morality in his time; rather, he believed that there were open metaphysical questions, such as the existence of the afterlife, and that, given differing human temperaments and feelings, the combination of belief, which has an evidentiary basis that justifies some level of assurance about what exists, and imaginative supernatural hope, which is "desire combined with expectation" (Notes on the Analysis, XXXI: 215) about what is real that is not contradicted by experience and that inspires moral conduct and helps one cope with life's suffering, might be part of any future enlightened age.

Mill long held that the best religious believers and non-believers share the same ultimate aims and feelings - ideals of honesty, self-sacrifice, love of fellow creatures, and desire to be of use in the world. He believed that these moral ideals, and not theological dogmas and Church traditions, are the essence of true Christianity, exhibited by Jesus in the gospels, and he was amazed that there were not more Christians "who perceive that Xtianity [Christianity] ... forms a point of union for all men in this point of view" (Letter to Thomas Dyke Acland, Dec 1, 1868, XVI: 1499). Religious believers have been taught to judge that if others do not share their theological dogmas - of the atonement, original sin, salvation by faith alone, predestination - there can be no unison between them and unbelievers. For Mill, it was necessary "to establish a bond of union - public spirit \& 
practical good deeds - between all disinterested men," (XVI: 1501) regardless of their religious or metaphysical opinions. Mill thus understandably claimed that the best unbelievers "are more genuinely religious, in the best sense of the word religion, than those who exclusively arrogate to themselves the title" (Autobiography, I: 47) because such unbelievers have a truly universal point of view - the priority of graces of character and the good of others - and do not divide and stigmatize people based on inconsequential theological opinions.

Moreover, as a moral and social reformer, Mill disagreed with those who thought philosophy could simply replace supernatural religion since any successful reform of religion would require the preservation of the core of Christian belief. As a student of history, Mill recognized that religion - "the spring and regulator of energetic action" (Diary Entry, Jan 23, 1854, XXVII: 646) - had been essential in guiding and inspiring humans to live morally and to help them cope with life's suffering, and he lived in an age in which Christianity was the foundation of morality and the framework for law, government, and university education. Successful reform required preserving the best elements of the Christian tradition and inspiring religious believers "to systematize and rationalize their own creed" (Coleridge, X: 163). As Mill proclaimed in On Liberty, it would be wise for heretical opinion to seek conciliation with the truth contained in common opinion rather than contradict it and set itself up as the whole truth (Liberty, XVIII: 252). In his 1840 essay Coleridge, Mill asked:

What is the use, then, of treating with contempt the idea of a religious philosophy? Religious philosophies are among the things to be looked for, and our main hope ought to be that they may be such as fulfill the conditions of a philosophy - the very foremost of which is, unrestricted freedom of thought. (Coleridge, X: 160)

At the beginning of Utility of Religion, Mill rendered his interpretation of the crisis of religious belief in Victorian society. ${ }^{4}$ The credibility of religious belief had been seriously undermined - internally, by the historical-critical method in Biblical studies demonstrating that there is no supernatural origin to religious scriptures, and externally, by the success of the natural and emerging social sciences in explaining phenomena based on human and natural, and not supernatural, causes. These developments led both unbelievers and rational religious believers to raise a novel question about religion - might it be useful to believe religion for the sake of individual and social welfare even if its truth is doubtful? This stage of weak belief - which represented for Mill a transitional stage in history, what the Saint Simonians categorized as a "critical age, when there is a loss of commonly held worldview" - led to different kinds of unsettling predicaments. Rational believers were led to avow what they could not intellectually believe since they believed it to be good for society to believe, a state that Mill describes as the "wish to believe" (Utility of Religion, X: 403)..$^{5}$ On the other hand, religious sceptics who valued truth and the general good, such as Mill, were put in the painful predicament of possibly doing social harm by making their honest estimation of religion known. Mill's purpose in Utility of Religion was to explore whether there is any intrinsic power to traditional supernatural religions that make them necessary for social and individual good or whether it is possible and desirable to reorient thinking away from unknowable supernatural beliefs and focus on the improvement of humanity in this world. 
LOU J. MATZ

Mill was not only writing in a transitional age of religious belief but also in a climate of legal and social persecution toward outspoken critics of religion and Christianity. ${ }^{6}$ The Toleration Act of 1689 that followed the Glorious Revolution in England opened up freedom of worship for Protestant Dissenters, and several religious reforms were enacted during Mill's life that removed legal restrictions for Dissenters, Catholics, and Jews; however, unbelievers were still subject to the law of blasphemous libel and other legal statues, such as the requirements to take a religious oath for public office or during trials or to enter the universities. In 1823, Mill, at the age of seventeen, wrote five letters to the Morning Chronicle (two were not published due to their content) defending religious liberty in reaction to the 1817 blasphemy prosecution of William Hone, who wrote liturgical parodies, and to the 1819 blasphemy conviction and imprisonment of Richard Carlile, who published Thomas Paine's The Age of Reason. When Mill was writing On Liberty, he lamented that while unbelievers were no longer threatened with death, there was no security in the public mind in England since law and social sentiment about religion created a climate of potential intolerance that could turn at any moment into active persecution. The worst part of this climate was not legal persecution but the stigmatization of free-thinkers as immoral, which Mill considered the worst offence committed by any religious polemic (Liberty, XVIII: 259). This climate motivated Mill to refrain from publishing anything in his lifetime devoted exclusively to religion. His father, James Mill - who had been a licensed Presbyterian minister but lost his faith and raised his son without any religion and impressed on him the moral evils of religion - instructed him that it was prudent to keep his religious beliefs private. And Mill did so, not wanting to jeopardize his influence as a social reformer by revealing his views on religion and Christianity. ${ }^{7}$ Mill also refused to be interrogated about his religious opinions during his MP candidacy for Westminster; he stated in a letter,

no one has any right to question another on his religious opinions; that the tree ought to be judged, and can only be judged, by its fruits; and I hold myself bound ... for the sake of future candidates, not to do any thing that may facilitate raising a religious cry against a person who may be unassailable as a politician. (Letter to Charles Westerton, Jun 21, 1865, XVI: 1069)

The jurist Fitzjames Stephen speculated that Mill could have been prosecuted and excommunicated had his Three Essays on Religion been published earlier. ${ }^{8}$

\section{Religious Morality}

Mill did, however, make public in On Liberty his analysis of Christian morality by adopting the most difficult test case - freedom of religious belief - to assess the cogency of his arguments defending liberty of thought and discussion. To limit the expression of religious opinion might rob society of noble moral doctrines. The Athenians persecuted Socrates because they thought he undermined the social order, but Socratic philosophy prevailed as a liberating force for mental development. The wise Roman emperor Marcus Aurelius persecuted Christianity because he thought it was detrimental to the social order, yet he failed to see that Christianity would be a force of good and a renovating 
agency. By historical analogy, Christendom was in the same situation in its persecution of atheists and free-thinkers. To those who claimed that Christian morality was the truth, Mill contended that while Jesus' teachings were reconcilable with a comprehensive morality, they could not have been intended to be complete - the gospels refer to a pre-existing Greco-Roman morality, and many precepts are too general to guide in specific situations or difficult to interpret literally. The teachings were also defective, such as not recognizing the importance of political obligation and having a reactionary nature against paganism, that is, ideals of submissiveness, innocence, avoidance of evil, and asceticism rather than ideals of action, nobility, pursuit of the good, and fulfillment in life. Mill held that the inculcation of Christian morality as the entire truth was "becoming a grave practical evil, detracting greatly from the value of the moral training and instruction" and that to form the mind and feelings on an exclusively religious type without adding secular moral ideas would result in a "low, abject, servile type of character" (Liberty, XVIII: 256). The moral regeneration of humanity required both Christian and non-Christian moral teachings.

For Mill, real Christianity was found not in dubious theological doctrines but in Jesus' moral teachings in the Sermon on the Mount - to love one's neighbor, not to judge others unless one judges oneself by the same standard, the kingdom of heaven is for the poor, humble, and dispossessed, and that to be perfect, one should sell one's things and give to the poor. Mill had a long-standing admiration for Jesus, which was strengthened in the 1830s when he read the New Testament. ${ }^{9}$ He judged that the goodness of Christ's teachings "are surely in sufficient harmony with the intellect and feelings of every good man or woman, to be in no danger of being let go" (Utility of Religion, X: 417) and that the most valuable part of Christianity was the effect of Jesus' life and teachings on human character, a standard of excellence and source of motivation even for the "absolute unbeliever" (Theism, X: 487). Mill held that the complete spirit of utilitarianism was represented in the Golden Rule of Jesus. (Utilitarianism, X: 218).

Mill's analysis of Christian morality in On Liberty has led some commentators to charge that its disguised goal was to eliminate Christianity and to replace it entirely with a Religion of Humanity (Hamburger 1991; Raeder 2002; Sell 2004). This interpretation problematically assumes that traditional forms of Christianity are the essence of Christianity, and Mill clearly wanted to preserve the spirit, as well as many of the precepts, of Christian moral teaching. As Eisenach correctly observed, Mill's defense of liberalism in On Liberty depends not on dismantling Christianity but expanding its religious, historical and philosophical framework, a further development of the Reformation (Eisenach 1998: 228). Mill made this point in a letter where he defied "any one to point out in my writings a single passage that conflicts with what the best religious minds of our time accept as Christianity" (Letter to Charles Westerton, Jun 21, 1865, XVI: 1069).

For Mill, the great evil in ascribing a supernatural origin to morality was that it protected morality from being questioned and thereby inhibited moral progress. This religious consecration of morality was also theoretically untenable. In his 1833 essay Blakey's History of Moral Science, Mill gave his version of Plato's Euthyphro by debunking the divine command theory of morality, the theory that God does not merely command humans to do good but that God determines what is good and virtuous. One difficulty with this theory is that it makes morality arbitrary; unless God's will conforms to what is good, what God wills is arbitrary, and he must be obeyed because of his power 
and not his goodness: "he is not to be obeyed because he is good, for that implies a good which he could not have made bad by his mere will" (Blakey's History of Moral Science, $\mathrm{X}$ : 27). Another difficulty is that to judge scriptural morality as good implies that there is an independent standard separate from God's will and discoverable without revelation. Yet another problem is that the divine command theory makes morality mysterious; if precepts of scripture are not intrinsically good but are only good because God makes them good, the goodness of scripture

ought to be as mysterious and incomprehensible to us as the ceremonies of magic: nor could there on that supposition be any reason apparent to us, why we are not commanded to hate our neighbor instead of to love him. (X: 28)

For Mill, the alleged special force of Christian morality was not due to a supernatural origin but to the natural psychological effects of authority, early education, and public opinion on the human mind, an argument he made in Utility of Religion. Religious creeds are promulgated by social authorities, such as parents, governments, churches, and universities, and authority makes a strong impression on the human mind. Religious morality is also inculcated at an early age and gains an advantageous command over the feelings, an effect that later teaching does not have. Mill pointedly remarks that "early religious teaching has owed its power over mankind rather to its being early than to its being religious" (Utility of Religion, X: 410). However, the strongest force in maintaining religious morality is the power of social opinion to compel conformity. Unlike legal sanctions, social sanctions are practically impossible to escape given the social character of human life and the effects of internalization, a point Mill emphasized in On Liberty in his critique of the tyranny of the majority. Religious obligations that are not supported by social opinion do not have much effect on conduct. As evidence, Mill noted that dueling is a custom in England but clearly contrary to Christian morality. ${ }^{10}$ The implication of Mill's analysis of the effects of authority, early education, and public opinion is that a secular morality that wielded these powers could have as strong a command on thought and feeling as traditional religion.

\section{A Religion of Humanity}

In Utility of Religion, Mill argued that an otherworldly religion was unnecessary for social morality and individual good. He described a Religion of Humanity that is based on the idealization of earthly life, on the aspirations to develop one's character to the fullest and to advance the greatest happiness for all sentient creatures. These are the ideal objects of a religion of humanity, and they deserve to be called a "religion" since they express ideal excellence, which is ultimate and sovereign over all selfish objects of desire. Mill's characterization of this secular religion was sparse, but his account of the character virtues in On Liberty and his moral theory in Utilitarianism can fill in the details, and these works were written at the same time as Utility of Religion and Nature. The motivation to live up to these human ideals would not be any hope for reward in an afterlife but the approval of those, whether alive or dead, whom we admire. To those who claimed that a religion of humanity would not have the same kind of psychological 
and social power as supernatural religious belief, Mill countered that were a religion of humanity to harness the psychological forces of authority, early education and public opinion, it could take root and become the Weltanschauung in a society. Indeed, in Mill's discussion of the sanctions of morality in Utilitarianism, he claimed that were the natural feeling to be in unity with others

to be taught as a religion, and the whole force of education, of institutions, and of opinion, directed, as it once was in the case of religion, to make every person grow up from infancy surrounded on all sides both by the profession and the practice of it, I think that no one who can realize this conception, will feel any misgiving about the sufficiency of the ultimate sanction for the Happiness morality. (Utilitarianism, X: 232)

Mill then referred in this passage to Auguste Comte's account of a religion of humanity to illustrate this possibility.

Mill appropriated the label "Religion of Humanity" from Auguste Comte, the positivist philosopher and sociologist, and analyzed his version of a Religion of Humanity in Auguste Comte and Positivism (1865). Mill thought that the principal value of Comte's social philosophy was to discredit the notion that "moral authority can be maintained over society without the aid of religious belief" (Autobiography, I: 221) and to defend the possibility that the collective existence of humanity, the Grand $\hat{E}$ tre, could replace the traditional concept of God as an object of religious and moral commitment. Mill recognized that Comte's Grand Etre had an advantage over the traditional conception of an omnipotent God since it, unlike an omnipotent deity, needs human help to achieve its ends. Mill acknowledged that the notion of a religion without God would be thought in his age to be an absurdity by most all believers and non-believers but that it nonetheless fulfilled the goal of religion - a creed that is internalized and has ultimate authority over one's actions and feelings. Mill found Comte's attempt to systematize and ritualize a Religion of Humanity, though, to be an unseemly imitation of Catholicism. ${ }^{11}$

For Mill, a Religion of Humanity avoided the intellectual and practical problems of revealed religions, such as Christianity. It advanced intellectual and moral progress by instilling the importance of independent, critical thinking rather than dogmatically protecting beliefs by consecrating them as the product of a divine source. It was truly catholic and not sectarian with its focus on perfection of individual character and promotion of the greatest happiness. Its moral motivation was unselfish, which is contrary to the selfish effects of traditional Christianity on "common minds" that tempts believers to regard the fulfillment of moral duties as a means to personal salvation, a position that even Christ unfortunately adopts (Matthew 6:33), though Mill acknowledged that the most noble Christians did not view morality in this way. A Religion of Humanity focused on the joys and suffering in this world and not some problematical hereafter, and it did not lead to intellectual or moral absurdities, like hell for unbelievers or grace for the elect (Calvinism), a doctrine that Mill thought was inseparable from every form of Christianity in his day. Mill contended that it was possible to worship the Author of Nature and of the Gospel without perverting the moral sentiments only by focusing on the good in nature and the spirit of the gospels. In reply to those who believed that a non-supernatural religion made life insignificant and justified a self-indulgent carpe diem philosophy of life, Mill countered that the improvability of self and society "offers to the imagination 
and sympathies a large enough object to satisfy any reasonable demand for grandeur of aspiration" (Utility of Religion, X: 420).

Mill recognized that supernatural religions have a significant advantage over a secular religion with the prospect of an afterlife. He discerned a close affinity between religion and poetry in that both created, through the imagination and rooted in feelings and emotions, ideal conceptions that are more beautiful than realized in human life. Religion posits another world in which these ideal conceptions are realized, and the appeal of religion is powerful "so long as human life is insufficient to satisfy human aspirations ... so long as earthly life is full of sufferings" (Utility of Religion, X: 419). And Mill noted that for sensitive natures, the expectation of a reunion with loved ones in an afterlife is a warranted hope since it is not known to be false. Nonetheless, in the context of his argument in Utility of Religion, Mill argued that hope in an afterlife is neither necessary (e.g., Buddhists believe the highest good is self-annihilation, not self-preservation) nor desirable (eternal self-conscious existence without any escape might be a terror).

For Mill, a Religion of Humanity avoided the principal moral difficulty with traditional monotheism - the problem of evil, that is, that the amount and extent of suffering in the world are irreconcilable with a benevolent and omnipotent God. Mill's analysis of the problem of evil is contained in his essay Nature in which he rejected the standard of morality of Deism as well as any theory of a natural moral law. Deists believe that a good and all-powerful deity created the world but left it to work according to its own laws and that the ways of Providence exhibited in nature are good and worthy of imitation since they reflect a good and perfect deity. As a result, "nature" or the "natural" becomes a moral standard. Mill argued, though, that any definition of nature or natural cannot be a standard to judge the morality or goodness of actions since any definition would lead to absurdities. One definition of nature, which Mill considered to be the true scientific definition, is "the sum of all phenomena together with the causes which produce them, including not only all that happens, but all that is capable of happening" (Nature, $X: 374)$. Based on this standard, all that happens is natural and good, but phenomena such as natural disasters, disease, and predation demonstrate this standard to be absurd as a moral guide and contrary to Christian morality to take care of the weak and treat others with love. Mill stated,

For however offensive the proposition may appear to many religious persons, they should be willing to look in the face the undeniable fact, that the order of nature, in so far as unmodified by man, is such as no being, whose attributes are justice and benevolence, would have made, with the intention that his rational creatures should follow it as an example. (Nature, X: 383)

To identify certain aspects of nature as the standard of good in order to avoid Mill's reductio argument would be to introduce an entirely new standard:

either it is right that we should kill because nature kills; torture because nature tortures; ruin and devastate because nature does the like; or we ought not to consider at all what nature does, but what it is good to do. (Nature, X: 386)

At the end of Nature, Mill stated that a dualistic supernatural religion, such as Manicheanism, was the only one consistent with the facts of the world. 
In his An Examination of Sir William Hamilton's Philosophy (1865), Mill also rejected the theological move, still common today, to avoid the problem of evil by conceiving God as beyond human comprehension, that its qualities differ not just in degree but in kind from human qualities. This conception of God implies that there can be no justified judgments about God's moral character. Mill rejected this notion of God. If God is entirely "other," then on what basis should one worship God? Veneration is based on reverence for God's qualities. If God's qualities are different in kind and beyond human comprehension, then it's possible that God is not good. On this view, God's worthiness of worship is based solely on its power. In a famous passage that brought charges that Mill was an atheist and Satanist, he exclaimed,

I will call no being good, who is not what I mean when I apply that epithet to my fellowcreatures; and if such a being can sentence me to hell for not so calling him, to hell I will go.

(Examination, IX: 103)

\section{God, Afterlife, and Miracles}

In Theism, Mill evaluated different a posteriori and a priori arguments for monotheism, taking it rather than polytheism as the starting-point of his investigation since it is a better explanation for the unified, interconnected, and seemingly coordinated system of actions and reactions in the world. He found the first cause or cosmological argument to be lacking. The mind might extrapolate from the experience of cause and effects and posit a totality of causes and effects, and consequently postulate an antecedent cause for the totality - God - but events always have antecedent causes. And since the permanent substratum in which events happen can neither be created nor destroyed, Mill did not think there was an explanation for the origin of matter and force. Mill next dismissed the popular general consensus argument, that God must exist because most people believe in God, as a fallacious appeal to authority, and he casted doubt on the alleged universality of theistic belief. The ontological argument proved to be baseless since the mere mental conception of a thing does not imply anything about its existence. Due to its empirical and inductive character, the only argument for God's existence that could have any plausibility for Mill was the argument from marks of design in nature. Natural phenomena, such as the eye, resemble human artifacts since the parts are arranged to achieve an end and so appear to be designed. For Mill, the argument from design was not only analogical but inductive, an example of his inductive method of agreement. Mill construed the argument as follows:

(1) All parts of the eye conspire or work to produce sight.

(2) Eyes of many creatures share this property.

(3) Eyes have origins and their parts were brought together by a cause.

(4) A common cause, rather than a random occurrence of independent causes, explains how the parts of the eye come together to produce sight in so many creatures.

(5) Based on analogies from experience, it is plausible that an intelligent will produced the connection between the parts of the eye and the fact of sight through an antecedent Idea or purpose. 
The inductive character of the argument is that there are innumerable instances of "some connection through causation between the origin of the arrangements of nature and the ends they fulfill" (Theism, X: 450). Darwin's theory of natural selection, however, presented an alternative explanation; the human eye and power of sight are not the result of an intelligent designer but the result of modifications over an expanse of time of a simpler eye to a more complex one. Ultimately, while Mill recognized that Darwin's "startling" theory rested "on well ascertained facts" and that his theory "will form an era in thought" (Letter to Herbert Spencer, XVI: 1505), he did not think there was yet enough evidence to prove that accidental variations or chance could be responsible for causing the intricate relation of parts of the eye that made sight possible. Mill thus concluded that there was weak inductive evidence to support the hypothesis of creation by intelligence. This intelligent designer or architect of nature, however, was limited in skill due to the imperfections in nature (e.g., human limitations in intelligence and goodness and vulnerability to disease) and limited in power due to the nature and extent of unwarranted suffering. There was evidence, though, that this divine architect is benevolent since pleasure typically results from the normal functioning of the body. If God exists, it is thus limited in power and skill but benevolent, a deity such as Plato's demiurge in the Timaeus.

Regarding the existence of the afterlife, Mill investigated both non-religious and religious arguments. For non-religious arguments - such as found in Plato's Phaedo or Descartes' Meditations - Mill claimed that the scientific evidence was entirely inconclusive. Brain diseases and impairment gave ample evidence that the brain is a condition sine quâ non of mental operations, and these operations uniformly coexist with brain activity. However, Mill warned that uniform coexistence does not imply a metaphysical necessity. He found no evidence that disembodied souls remain on earth or interfere with events but contended it is possible that mental states may continue or recommence elsewhere under different conditions. To those who say that the fate of consciousness is no different than other objects of nature and hence perish like them, Mill responded that the negative evidence against immorality is different since "all matter apart from the feelings of sentient beings has but an hypothetical and unsubstantial existence" (Theism, X: 463). Hence, the lack of evidence for immortality is not as conclusive as it is, say, for witchcraft. Mill ultimately asserted that the reasons for belief in immorality were not based on empirical evidence but on the wish for continued existence and the force of social opinion. Mill pointed out, however, that the consoling nature of an opinion cannot justify its status as a belief, which has an evidentiary basis, and that the doctrine that consoling opinions ipso facto provide a basis for belief would sanction all kinds of mischievousness and mislead individuals in their lives.

Mill also dismissed the religious argument for immortality. If there is a good God with limited power, there is no basis to think that it could grant life after death. However, there is room to hope, for those who find it useful, that such a being might grant this gift since there is some evidence that this being seeks human good. Mill speculated that if there is an afterlife, its character is such that the consequences of our actions and character in this life will follow us into the next life, and he further imagined that a feature of the afterlife might be the best feature of this one: improvability by our own efforts.

Mill then considered the reality of miracles or revelation and reaffirmed the position he stated at the end of Book III in his System of Logic. He judged Hume's analysis to be 
conclusive and strengthened by the progress of scientific explanation, which showed that all phenomena are amenable to law. Miracles are violations of the observed uniform course of nature where effects follow antecedent causes and never occur without the appropriate collection of physical conditions. Any claim about a supernatural cause is not based on direct evidence of perception but on an inference to the unobserved. The existence of God cannot be proved by miracles since an alleged miraculous event can be explained by a more probable hypothesis, for example, the falsity of testimony or the existence of an unknown physical law or the existence of unknown antecedent conditions that produce the effect according to a law. For Mill, miracles had no claim as historical facts. Miracles are evidence of revelation only for those who already presuppose the existence of God, but even then there is a choice of what is most probable between a divine explanation or a naturalistic one (Letter to William George Ward, XIV: 26). For miracles to be a serious possibility, there must be independent evidence for the existence of a benevolent deity.

\section{Rational Belief and Imaginative Hope}

Mill's final statement of his philosophy of religion comes at the end of Theism in reply to the question whether feelings and opinions must be regulated strictly by empirical evidence. Mill contended that the provinces of reason and the imagination can operate independently and that it is legitimate for the imagination, in reaction to the skepticism of the understanding, to cultivate supernatural religious hopes as long as they do not subvert the intellect or moral judgment. Even with the continual material and moral improvement of human society, some persons might, depending on their sensitivities, need inspiration and the comfort that the imagination provides by hoping in a realm beyond the human, and it is part of wisdom to furnish the imagination with any probabilities and possibilities. When reason is strongly cultivated, the imagination may make "life pleasant and lovely inside the castle" (Theism, X: 485). Mill adduces as evidence the example of cultivating a cheerful disposition. Based on the evidence, there might not be grounds for a cheerful and optimistic outlook in life, yet it is wise to cultivate one, and this outlook need not be detrimental to one's welfare or the welfare of others. Based on this principle, the indulgence of hope about God and an afterlife is legitimate, and the benefit is real - supernatural hopes elevate the feelings, provide a balm to cope with loss, and inspire people to improve their character and advance the good of others.

Mill concluded Theism by asserting that the most animating and invigorating thought that can inspire a person is to know that one has done something to help advance goodness in the world. To fortify a religion of humanity with supernatural hopes - that humans are working with an all-good but limited-in-power deity to advance good in the world, that there is an afterlife, and that Jesus' "stamp of personal originality combined with profundity of insight" (Theism, X: 487) might have been commissioned by this deity - could motivate traditional Christian believers to adopt a Religion of Humanity and is one example of the possible complementary relationship between rational belief and imaginative hope, making reason and supernatural religion partners, and not antagonists, in "cultivating a religious devotion to the welfare of our fellow-creatures as an obligatory limit to every selfish aim" (X: 488). 
Mill's view on religion presented challenges to both religious skeptics and religious believers. August rightly notes that the rancorous reception of Mill's Three Essays demonstrated that "once again the intricacies and alterations of his thought were too much for party-line thinkers" (August 1975: 246). As a utilitarian and social reformer, Mill could not dismiss the value of religious hopes since they might elevate and inspire self-development and the commitment to others without subverting the intellect and moral feelings. Mill experienced living examples of this possibility among his Unitarian friends, who included his future wife Harriet Taylor and the Unitarian leader, W.J. Fox, whose religion Mill described as

the most unobtrusive kind ... what the religion of all denominations would be, if we were in a healthy state - a religion of spirit, not of dogma, and catholic in the best sense. (Mill, Letter to John Pringle Nichol, Jan 17, 1834, XII: 210)

The challenge for the rational sceptic is to recognize the variety of individual sensitivities and feeling and that certain kinds of religious hopes can have psychological and moral value as long as they are properly bounded. Religious hope need not be rejected as irrational or infantile simply because it meets human emotional needs. An enlightened society can be composed of various supernatural religious traditions and beliefs that can reformed to be consistent with what is known.

On the other hand, Mill's conception of religion challenged traditional Christian believers. Contrary to critics like Hamburger, Raeder, and Sell, Mill did not seek to eliminate Christianity. Rather, he sought to recover the essence of Christianity unencumbered by immoral or indefensible theological dogmas. Jesus was to be understood as human, not divine, and the belief in a Providential deity must be rejected. The ideas of miracles and an afterlife must be relegated to the region of religious hope, of mere theoretical possibilities, and not held with the conviction of beliefs. Jesus' alleged resurrection was a later addition or interpolation. Religious writings and tradition must be evaluated by reason, a position the Unitarians promoted. Law and morality cannot be based on scripture but on independent reasons, and complete liberty of religious opinion must be protected by law and encouraged by social opinion. Parents should raise their children to value questioning and critical examination of ideas ${ }^{12}$ and that it is not a duty to believe and a sin to doubt. ${ }^{13}$ The highest good is personal development and the happiness of others. Religions that can reform their narratives and traditions to accord with these principles are to be respected.

\section{Assessment of Mill's Philosophy of Religion}

Several commentators (Bain 1882; August 1975; Carr 1962; Sell 2004) have speculated that Mill's defense of supernatural hope marked a significant change in his thinking about religion as a result of the death of Harriet Taylor in 1858, which occurred after he wrote Nature and Utility of Religion but before he wrote Theism. However, as early as 1847, Mill recognized the legitimate role of the imagination to entertain conjectures about metaphysical questions, such as the existence of a Creator, when there is no proof against it (Enlightened Infidelity, XXIV: 1083), and he recognized at the end of Utility of 
Religion that "the more sensitive natures" will keep alive the imaginative hope of a futurity; Mill long had what Morley described as "a deep-eyed solicitude for tender consciences, an anxious allowance for diversity of mental operation and temperament" (Morley 1875: 103).

Mill's consideration of the relationship of rational belief and imaginative hope at the end of Theism is a fitting denouement to his scientific analysis of the main tenets of supernatural religion, and I concur with Britton (1976) that Mill's main contribution to the philosophy of religion was his delineation of the realms of reason and imaginative hope. It is necessary, though, to distinguish between Mill's general project of delineating these realms from his specific examples of imaginative hope. His defense of the objects of imaginative supernatural hope turns on the cogency of the design argument, however, this foundation is fatally undermined by the truth of evolution, the best explanation for the appearance of design among living entities. There is thus on Mill's own terms no basis to harbor either a low-probability belief that a designer deity exists or imaginatively hope that it has the power to bestow an afterlife or send a moral exemplar like Jesus into the world. Early reviewers of Mill's Three Essays criticized his lack of appreciation of the evidence for natural selection, and it is perplexing that Mill, who read Hume's Dialogues Concerning Natural Religion and praised its mode of argument, did not consider Philo's objections to the design argument in Part V, for example, experience shows that the creation of complex entities requires multiple intelligences, and not one, that intelligence is always embodied, and that it is arbitrary and anthropocentric to privilege intelligence as the origin of design rather than other known causal powers, such as instinct, generation, or vegetation.

Mill's defense of the realms of rational belief and imaginative hope does not, though, necessarily depend on his defense of the design argument. There are other imaginative possibilities for supernatural realities - such as the Manichean force of goodness - that might inspire moral commitment and the courage to endure hardship. But is Mill's delineation of realms plausible? Sell contends that Mill's naturalism and positivism theoretically preclude grounds to defend legitimacy of imaginative hope, but he does not appreciate that Mill's utilitarianism makes the appeal to the usefulness of hope a legitimate consideration for human well-being, Nonetheless, commentators have rightly questioned whether purely theoretical possibilities that have not been proven false can actually sustain hope, especially when there is overwhelming evidence against them. Bain argued that

Mill hardly does justice to the natural difficulties of reproducing human existence, after death, for an eternal duration; and yet casts doubts on the omnipotence of the Power that is to perform the miracle. (Bain 1882: 135)

and Millar pointed out that

it is one thing to be hopeful about what for all we know might be the case when we think there is at least some chance that it may be so. It is another to indulge hope where we have no reason to think there is such a chance. This latter speculative hope is what Mill enjoins. (Millar 1998: 198) 
These points are well-taken, yet experience seems to show that theoretical possibilities can be psychologically motivating. It would be a worthwhile empirical study to determine whether, and in what ways, the indulgence of imaginative supernatural hopes might, or might not, be detrimental to rational thinking in other realms.

Commentators are correct that Mill was not well-versed in theological writings (Bain 1882) and did not address some important Christian theological doctrines in his analysis (Sell 2004), and they claim that these shortcomings make Mill's analysis of Christianity less convincing. However, these shortcomings do not materially affect Mill's critical assessment of the grounds to believe the most important tenets of monotheism and Christian theology - the existence of an all-powerful and benevolent deity, miracles, and the divinity of Christ. Moreover, Mill's objection that traditional religion is not acceptable to rational minds helps to explain the rise of secularism and religious non-identification in countries like England and the United States. There is no Religion of Humanity so-named, but secular humanist organizations abound, and the percentage of the population in England and the United States that identifies with no religion is on the rise. For example, in the 2011 UK census conducted by the Office of Statistics, $59 \%$ of the population identified as Christian, and $25 \%$ identified as "no religion," a $10 \%$ increase from the previous census ten years prior.

In his Autobiography, Mill characterized religion as the "region of ultimate aims," and he identified two realms for those who aspire to improve human life: the region of ultimate aims, and the useful and practically attainable. For Mill, the essence of religion is the moral improvement of humanity and the consolation it can provide in life, and so religion is both an ultimate aim and practically useful. And his philosophy of religion represented his attempt to reconcile his deepest conviction about the region of ultimate aims - the moral improvement of humanity - with his unwavering epistemological commitment that all beliefs must be warranted by sufficient evidence. ${ }^{14}$

\section{Notes}

Lowe (1874: 110).

2 For an introduction to the Three Essays, see Matz (2009).

3 Such as Richard Dawkins, Sam Harris, Christopher Hitchens, and Daniel Dennett.

4 Mill also briefly describes the predicament at the beginning of Chapter 2 of On Liberty.

5 Modern-day philosophers like Daniel Dennett have characterized this condition "belief in belief."

6 For an account of the legal climate, see Hamburger (1991).

7 Haac, Oscar A., trans. 1995. The Correspondence of John Stuart Mill and Auguste Comte. Brunswick, NJ: Transaction Publishers, 42. See also Letter to Thomas Carlyle, Jan 12, 1834, XII: 206.

8 See Hamburger (1991).

9 Letter to Thomas Carlyle, Jan 12, 1834, XII: 208.

10 Mill's example comes from Jeremy Bentham's Analysis of the Influence of Natural Religion on the Temporal Happiness of Mankind (1822), which inspired Mill's writing Utility of Religion. Bentham's essay can be found in Crimmins (1998).

11 For Mill's analysis of Comte's religion of humanity, see his Auguste Comte and Positivism, $\mathrm{X}: 332 \mathrm{ff}$. 
MILL'S PHILOSOPHY OF RELIGION

12 Letter to Charles Friend, Oct 29, 1868, XVI: 1468-9.

13 Theism, X: 480.

14 Thanks to Alan Millar, Eldon Eisenach, and Monica Libell for their helpful comments on drafts of this chapter.

\section{References}

August, Eugene. 1975. John Stuart Mill: A Mind at Large. New York: Charles Scribner's Sons.

Bain, Alexander. 1882. John Stuart Mill: A Criticism with Personal Recollections. London: Longman, Green and Co.

Britton, Karl W. 1976. "John Stuart Mill on Christianity." In James and John Stuart Mill/Papers of the Centenary Conference, edited by John M. Robson and Michael Lane, 21-34. Toronto, Canada: University of Toronto Press.

Carr, Robert. 1962. "The Religious Thought of John Stuart Mill: A Study in Reluctant Scepticism." Journal of the History of Ideas, 23(4): 475-95.

Crimmins, James. 1998. Utilitarians and Religion. Bristol, UK: Thoemmes Press

Eisenach, Eldon J. 1998. Mill and Liberal Christianity." In Mill and the Moral Character of Liberalism, edited by Eldon J. Eisenach, 191-229. University Park, Pennsylvania: The Pennsylvania State University Press.

Hamburger, Joseph. 1991. "Religion and On Liberty." In A Cultivated Mind: Essays on J.S. Mill Presented to John M. Robson, edited by Michael Laine, 139-81. Toronto, Buffalo, London: University of Toronto Press.

Lowe, Charles. 1874. "The Religious Views of John Stuart Mill." Unitarian Review and Religious Magazine, I(2): 101-12.

Matz, Lou, ed. 2009. Three Essays on Religion. Ontario, Canada: Broadview Press.

Millar, Alan. 1998. "Mill on Religion." In The Cambridge Companion to Mill, edited by John Skorupski, 176-202. Cambridge, UK: Cambridge University Press.

Morley, John. 1875. "Mr Mill's Three Essays on Religion." The Fortnightly Review, January 1875, 103-31.

Raeder, Linda. 2002. John Stuart Mill and the Religion of Humanity. Columbia, Missouri: University of Missouri Press.

Sell, Alan. 1997. Mill and Religion: Contemporary Responses to Three Essays on Religion. Bristol, UK: Thoemmes Press. 2004. Mill on God: The Pervasiveness and Elusiveness of Mill's Religious Thought. Hampshire, UK: Ashgate Publishing.

\section{Further Reading}

Ryan, Alan. 1974. J.S. Mill. London and Boston: Routledge \& Kegan Paul. 